$$
\begin{aligned}
& R \mathrm{H}-\sim \rightarrow R \cdot+\mathrm{HS} \cdot \mathrm{CH}_{2} \cdot \mathrm{CH}_{2} \cdot \mathrm{NH}_{2} \rightarrow R \mathrm{H}+ \\
& R \mathrm{H} \longrightarrow \sim \rightarrow R \cdot+\mathrm{O}_{2} \rightarrow R \mathrm{O}_{2}
\end{aligned}
$$

This hypothesis will be tested further by investigating the quantitative relations between lowered oxygen tension and the concentration of MEA in the tissues on the radiation sensitivity of hypothermic mice.

Robert-Rössle Klinik,

E. MAgDoN

Lindenberger Weg, 80,

Berlin-Buch, Germany.

${ }^{1}$ Bacq, Z. M., Herve, A., Zecomte, I., Fischer, P., Blavier, I., Dechamps, G., Le Bihan, H., and Rayet, P., Arch. Intern. Physiol., 59, 442 (1951).

${ }^{2}$ Alexander, P., Bacq, Z. M., Consens, S. F., Fox, M., Herve, A., and Lazar, I., Rad. Res., 2, 392 (1955).

${ }^{3}$ Doherty, D. G., Burnett, W. T., and Shapira, R., Rad. Res., 7, 13 (1957).

4 Galerno, P. R., and Friedell, H. L., Fed. Proc., 12, 364 (1953).

${ }^{5}$ Gray, L. H., Prog. Radiobiol., 267 (Oliver and Boyd, Edinburgh, 1956).

${ }^{8}$ Eldjarn, L., and Pihl, A., Rad. Res., 8, 110 (1958). ${ }^{7}$ Eldjarn, L., and Pihl, A., in Mechanisms in Radiobiology, edit. by Errera,
M., and Forssberg, A.,2, 231 (Academic Press, New York, 1960).

${ }^{8}$ Magdon, E., Strahlentherapie (in the press)

${ }^{9}$ Fallowfleld, T. L., Int. J. Rad. Biol., 4, 457 (1962).

${ }^{10}$ Weber, E., Grundris8 der biologischen Statistick, 395 and 498 (Gustav Fischer Verlag, Jena, 1961).

${ }^{11}$ Patt, H. M., Blackford, M. E., and Straube, R. L., Proc. Soc. Exp. Biol., N.Y., 80, 92 (1952)

${ }_{12}$ Weiss, L., Int. J. Rad. Biol., 3, 285 (1961),

${ }^{13}$ Ormerod, M. G., and Alexander, P., Rad. Res., 18, 495 (1963).

\section{Semi-automatic Transfer of Volatile Liquids to Paper Chromatograms}

THE recent publication of a device for applying liquids to paper chromatograms ${ }^{1}$ prompts this report of a simple arrangement for the reproducible transfer of small volumes which is in routine use in this laboratory for the application of steroid standards to paper chromatograms. It consists of a lambda pipette clamped in the vertical position with the pipette tip firmly against the surface of the chromatography paper which is supported on a perforated metal disk. A stream of compressed air for drying passes through holes in the metal disk against the lower surface of the paper (Fig. 1). In practice the pipette is filled with solvent and positioned while keeping a finger over the upper orifice to prevent leakage. Gradual transfer of solvent to paper begins when the finger is released. A Medtec Spotting Device was employed, but a simpler device for support of the paper and delivery of a gas stream would serve the purpose.

Experiments were performed with a variety of solvents (100-500 $\mu 1$. volume) containing Sudan III as indicator, together with Whatman No. 2 chromatography paper and compressed air stream at room temperature. The

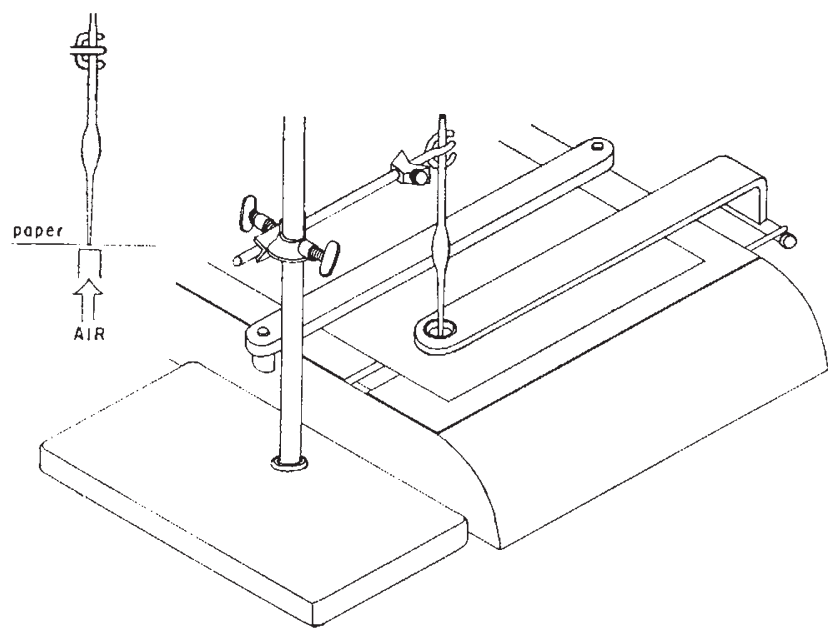

Fig. 1. Device for transfer of liquids to paper chromatograms spots which occurred using chloroform, benzene, ethyl acetate, or dichloromethane had diameters of $7 \mathrm{~mm}$ or less, while those with methanol were less satisfactory (8 $\mathrm{mm}$ diameter). Unsatisfactory results were obtained with water, due to tearing of the paper or spread of the solvent over a large area despite attempts to hasten drying by use of an infra-red lamp.

The time required to deliver $500 \mu \mathrm{l}$. chloroform was $7.5 \mathrm{~min}$, benzene $14 \mathrm{~min}$, and ethyl acetate $23 \mathrm{~min}$. Transfer of solute to the metal disk is negligible provided the air stream is moderately vigorous and drying is effective. This device is applicable to wide chromatography paper, and semi-automatic delivery allows several chromatograms to be spotted in parallel if desired. The chief limitation appears to be the inability to handle large solvent, volumes. Our spots appear to be slightly larger than those reported by Clarke and Sowter ${ }^{1}$, perhaps because we used an air stream at ambient temperature, a choice which was dictated by the thermolabile nature of the solutes.

This investigation was supported by U.S. Public Health Service research grant $A M-06607$ and training grant $2 A-5230$, National Institute of Arthritis and Metabolic Diseases, and by the Oregon Heart Association.

\section{RICHARD E. BAILEY}

Helen P. Pieters

JAMES H. BECK

Division of Diabetes and Metabolism,

Department of Medicine,

University of Oregon Medical School, Portland.

${ }^{1}$ Clarke, E. G. C., and Sowter, S. A., Nature, 202, 795 (1964).

\section{Inhibition of Synthesis of Acetylcholine by Some Esters of Trimethoxybenzoic Acid}

Hemicholinium (HC-3) has been shown to possess a strong inhibitory effect on acetylcholine (ACh) synthesis in nervous tissue which can be effectively antagonized by choline ${ }^{1-6}$. Similar activity, though to a lesser degree, has been demonstrated in tetraethylammonium $(T E A)^{7,8}$. Replacement of the ethyl group of TEA by methyl, propyl or butyl results in a significant reduction of the inhibitory activity. Recently, we have demonstrated that troxy. pyrrolidinium (ethyl-2(3,4,5-trimethoxybenzoyloxy) ethyl pyrrolidinium iodide) possesses hemicholinium-like activ ity but is less toxic ${ }^{9}$. In the work recorded here, a series of trimethoxybenzoic acid esters are compared to determine the structure/activity relationship.

As shown in Table 1, the common feature in all compounds is the 'aminoethanol' moiety:

$$
\left(\frac{+}{\mathrm{N}}-\mathrm{C}-\mathrm{C}-\mathrm{O}-\stackrel{\mathrm{O}}{\mathrm{C}}-R\right)
$$

where the nitrogen is quaternized and the oxygen is linked to carbon which is in the carbonyl form. These compounds produce the characteristic toxic features of $\mathrm{HC}-3$ (muscular weakness and respiratory depression at sublethal doses and respiratory paralysis followed by asphyxial convulsions at lethal doses). The $L D_{50}$ (intraperitoneal) for mice, estimated by the method of probits ${ }^{10}$, is shown in Table 1. Like HC-3, the toxic effects of all the compounds, with the exception of trimethylammonium (I), the morpholino derivatives with propyl (V) and butyl (VI) ester linkage, could be effectively antagonized by choline. The optimal protective dose of choline (100 $\mathrm{mg} / \mathrm{kg}$ ) raised the $L D_{50}$ value $2-3$ times. The compounds produced failure of transmission in the cat's superior cervical ganglion stimulated presynaptically at high frequency $(20$ shocks/sec). The ganglia lost 60-70 per cent of the preformed stores of ACh when stimulated for $30 \mathrm{~min}$ in the presence of triethylammonium (troxonium - 